\title{
MITIGASI COVID-19 MELALUI KONTEN KREATIF DI MEDIA SOSIAL
}

\author{
'Saefuddin, ${ }^{2}$ La Ode Santiaji Bande, ${ }^{3 *}$ Hasmina Tari Mokui \\ ${ }^{1}$ Fakultas Keguruan dan IImu Pendidikan, Universitas Halu Oleo \\ ${ }^{2}$ Fakultas Pertanian, Universitas Halu Oleo \\ ${ }^{3}$ Fakultas Teknik, Universitas Halu Oleo \\ Email: saefuddin@uho.ac.id, santiaji.bande@gmail.com, hasmina.tari.mokui@gmail.com \\ ${ }^{*}$ Corresponding Author \\ Kendari, 93232, Indonesia
}

\begin{abstract}
This Thematic Real Work Integrated with Community Service aims to increase the literacy of the people of Southeast Sulawesi regarding COVID-19 and how to mitigate it by using creative content media. This thematic program is one form of community service, so that its implementation follow the action research method with 5 (five) stages, i.e. (1) Diagnosis; (2) Planning; (3) Implementation; (4) Evaluation; and (5) Special learning. This thematic program was attended by 22 students under supervision of three field lecturers and lasted for 30 days online. During this program, more than 20 posters/e-cards and 30 videos have been produced. The content has been disseminated on various social media through the accounts of students and supervisors as well as other internet media. Based on the results of creative content in the form of posters, the public can improve their literacy on social and physical distancing as an effort to accelerate COVID-19 mitigation. Meanwhile, creative content in the form of videos can train the public on how to use and prepare their own hand sanitizer, masks, and PPE by utilizing materials found around them. Thus, it can be concluded that this thematic program has succeeded in providing guidance and debriefing to the people of Southeast Sulawesi as a mitigation effort against the COVID-19 outbreak.
\end{abstract}

\section{Keywords: COVID-19; Corona Virus; Community Service; Creative Content; KKN-Thematic; Social Media}

\begin{abstract}
Abstrak
Kegiatan Pengabdian Masyarakat Terintegrasi Kuliah Kerja Nyata (KKN) Tematik ini bertujuan untuk meningkatkan literasi masyarakat Sulawesi Tenggara mengenai COVID-19 serta cara mitigasinya dengan menggunakan media konten kreatif. KKN Tematik merupakan salah satu wujud community service, sehingga tahapan pelaksanaannya mengikuti metode action research dengan 5 (lima) tahapan yaitu (1) Diagnosis; (2) Perencanaan; (3) Pelaksanaan; (4) Evaluasi; dan (5) Pembelajaran khusus. KKN-Tematik ini diikuti oleh 22 orang mahasiswa di bawah bimbingan tiga orang dosen pendamping lapangan dan berlangsung selama 30 hari secara daring. Dari program KKN-Tematik ini telah dihasilkan lebih dari 20 poster/e-card dan 30 buah video. Konten tersebut telah disebarkan di berbagai media sosial melalui akunakun mahasiswa dan dosen pembimbing serta media internet lainnya. Berdasarkan hasil konten kreatif dalam bentuk poster, masyarakat dapat ditingkatkan literasinya mengenai social dan physical distancing sebagai upaya percepatan mitigasi COVID-19. Sedangkan konten kreatif berupa video dapat melatih masyarakat mengenai cara penggunaan dan penyiapan cairan pencuci tangan (hand sanitizer) sendiri, masker dan APD dengan memanfaatkan bahan- bahan yang terdapat di sekitar. Dengan demikian, dapat disimpulkan bahwa Kegiatan KKN-Tematik ini telah berhasil mewadahi pembimbingan dan pembekalan kepada masyarakat Sulawesi Tenggara sebagai upaya mitigasi terhadap wabah COVID-19.
\end{abstract}

Kata Kunci: COVID-19; Corona Virus; Konten Kreatif; KKN-Tematik,; Media Sosial; Pengabdian Masyarakat

Open Access at:http://ojs.uho.ac.id/index.php/PUBLICUHO/index

Journal Publicuho is licensed under a Creative Commons Attribution 4.0 International License. 


\section{Journal Publicuho}

ISSN2621-1351 (online), ISSN 2685-0729 (print)

Volume 4 Number 3 (August - October), 2021 pp. 834-845

Accredited SINTA SK.NOMOR 28/E/KPT/2019

Open Access at:http://ojs.uho.ac.id/index.php/PUBLICUHO/index

DOI: $10.35817 / j p u . v 4 i 3.19663$

\section{PENDAHULUAN}

Saat ini masyarakat di seluruh dunia sedang berjuang melawan wabah penyakit yang diakibatkan oleh virus corona. Secara umum penyakit tersebut dikenal dengan istilah corona virus disease atau COVID-19. Penyebaran virus diduga bermula di kota Wuhan, Provinsi Hubei, Cina pada 31 Desember 2019 ini dengan sangat cepat menyebar ke seluruh belahan dunia, sehingga badan kesehatan dunia World Health Organization (WHO) mengeluarkan pengumuman pandemi global COVID-19 pada 11 Maret 2020. Di Indonesia, COVID-19 ini mulai mewabah pada 14 Maret 2020 dan serta merta mengubah beberapa tatanan kehidupan, termasuk dalam bidang pendidikan (Bdair, 2021; Feldman, 2020; Jogezai et al., 2021; Lapitan et al., 2021).

Bagi bangsa Indonesia, dampak pandemic COVID-19 ini telah berimbas pada segala sector kehidupan masyarakat yang berakibat pada kompleksitas masalah dan upaya penanganannya. Rumitnya penanganan wabah COVID-19 membuat pemerintah mengambil beberapa kebijakan untuk menghambat penyebaran virusnya diantaranya dengan mengeluarkan pedoman mitigasi COVID-19 (Kesehatan, 2020). Inti dari pedoman tersebut adalah bahwa pembatasan interaksi sosial (social distancing), jaga jarak (physical distancing) maupun literasi pola hidup sehat adalah beberapa upaya yang harus dilakukan oleh masyarakat. Namun upaya tersebut di beberapa tempat tidak selalu berjalan seperti yang diharapkan. Kendala utama dalam upaya mitigasi wabah COVID-19 ini diantara diakibatkan oleh rendahnya literasi masyarakat tentang virus COVID-19 dan cara penyebarannya serta kurangnya pengetahuan masyarakat mengenai cara yang dapat mereka lakukan untuk memutus rantai penyebaran virus. Banyak diantara masyarakat kurang memahami cara mencuci tangan dengan benar, membuat cairan pencuci tangan yang sederhana, membuat masker maupun alat pelindung diri dari bahan di sekitar mereka ataupun cara membuat perangkat sanitasi otomatis sendiri (Mokui et al., 2021). Oleh karenanya, perlu dilakukan upaya konkrit untuk meningkatkan literasi masyarakat ini.

Sementara itu, pembatasan interaksi social (social distancing) dan jaga jarak (physical distancing) berimbas pada pelaksanaan pembelajaran pada lembaga pendidikan. Moda pembelajaran tatap muka di kelas diubah menjadi jarak jauh menggunakan media internet, seminar, diskusi dan kegiatan akademik lainnya juga disesuaikan sehingga esensinya tetap diperoleh dan tetap berpegang pada protokol Kesehatan dalam upaya mitigasi COVID-19 (Lapitan et al., 2021; Bdair, 2021). Dalam lingkup Universitas Halu Oleo (UHO), implementasi kebijakan pemerintah ini dalam bidang akademik adalah dikelvarkannya Surat Edaran Rektor No. 02/UN29/RT/2020 tanggal 16 Maret 2020, yang mengalihkan seluruh kegiatan akademik dan non akademik menjadi secara daring/dalam jaringan (online). 
Pengalihan kegiatan akademik secara daring serta merta mempengaruhi seluruh aktivitas tridharma UHO, termasuk kegiatan pengabdian masyarakat. Dengan merebaknya kasus COVID 19, kegiatan berbasis pelayanan terhadap komunitas sangatlah dibutuhkan (Amadasun, 2020). Program pengabdian kepada masyarakat terintegrasi Kuliah Kerja Nyata (KKN) Tematik merupakan salah satu agenda rutin akademik akademik UHO yang juga tetap bisa dilaksanakan dalam masa wabah COVID-19. Setiap mahasiswa tingkat sarjana wajib mengikuti program KKN yang merupakan perwujudan dari pengabdian kepada masyarakat. Selama masa KKN, mahasiswa diharuskan untuk menghasilkan produk karya pengabdian yang bertujuan untuk meningkatkan kapasistas masyarakat desa/kelurahan/lembaga yang merupakan mitra KKN tersebut. Tema KKN Tematik UHO selama masa pandemic adalah mitigasi COVID-19 oleh karenanya hal ini dapat menjadi sarana untuk mengedukasi mahasiswa peserta KKN dan masyarakat umum tentang COVID-19, terutama dalam usaha pencegahan penyebaran COVID-19.

Teknologi informasi dan telekomunikasi khususnya internet merupakan teknologi yang sangat dibutuhkan untuk mendukung setiap aspek kegiatan selama masa pandemik COVID-19. Internet telah terbukti mempermudah pelaksanaan kegiatan secara online, baik itu aktivitas pendidikan formal (Bdair, 2021; Lapitan et al., 2021; Wirani, 2020) ataupun penelitian tindakan (Feldman, 2020; Mohd Syafiq Aiman Mat Noor, Satirah Ahmad and Zailah Zainudin, 2020). Sebagai bagian dari teknologi informasi dan telekomunikasi, social media sangatlah memegang peranan penting dalam penyebaran informasi ke masyarakat. Berdasarkan penelitian (Zhao et al., 2020) di China, berita di social media merupakan salah satu sumber yang sangat menarik perhatian masyarakat dalam menerima informasi terkait COVID-19. Oleh karenanya, pemberitaan yang tepat melalui social media dapat membantu pemerintah dalam upaya mitigasi COVID-19 ini secara cepat dan tepat.

Rasa saling percaya antara pemerintah dan masyarakat merupakan unsur yang sangat penting dalam keberhasilan upaya mitigasi COVID-19 (Harring, Jagers and Löfgren, 2021). Penelitian di Nigeria (Agwu, Ugwu and Eke, 2020) terkait upaya mitigasi ini juga menyimpulkan bahwa pemerintah perlu meningkatkan akuntabilitasnya serta terhubung secara efektif ke seluruh lapisan masyarakat. Dengan banyaknya informasi serta hoax yang tersebar di media sosial, maka rasa percaya masyarakat akan informasi yang diterima sangatlah ditentukan oleh sumber informasi tersebut. UHO sebagai lembaga pendidikan negeri yang terbesar di wilayah Sulawesi Tenggara dapat mengambil peran dalam memberikan informasi yang benar dan tepat terkait COVID-19 ke masyarakat.

Kegiatan (KKN) Tematik ini bertujuan untuk meningkatkan literasi masyarakat Sulawesi Tenggara mengenai COVID-19 serta cara mitigasinya dengan menggunakan media konten kreatif. Karena dilaksanakan secara online, maka peserta program KKN Tematik yang tersebar di seluruh wilayah Sulawesi Tenggara dapat berkolaborasi via internet dalam 


\section{Journal Publicuho}

ISSN2621-1351 (online), ISSN 2685-0729 (print)

Volume 4 Number 3 (August - October), 2021 pp. 834-845

Accredited SINTA SK.NOMOR 28/E/KPT/2019

Open Access at:http://ojs.uho.ac.id/index.php/PUBLICUHO/index

DOI: 10.35817/jpu.v4i3.19663

menyebarkan visi misi pemerintah dalam upaya mitigasi COVID-19. Pada sub bab berikutnya akan dipaparkan metode pelaksanaan KKN Tematik serta hasil dan kesimpulan yang diperoleh selama pelaksanaan program ini.

\section{METODOLOGI}

Program pengabdian masyarakat terintegrasi KKN Tematik merupakan salah satu wujud community service, sehingga tahapan pelaksanaannya mengikuti metode action research yang dipaparkan oleh (Madden et al., 2014; Park, Chang and Jun Lee, 2017). Secara singkat, tahapan tersebut adalah (1) Tahap diagnosis; (2) Tahap perencanaan; (3) Tahap pelaksanaan; (4) Tahap evaluasi; dan (5) Tahap pembelajaran khusus. Seluruh kegiatan KKNTematik ini diupayakan akan dilaksanakan tanpa tatap muka secara langsung, melainkan secara daring, mulai dari tahap pendaftaran, seleksi, pelaksanaan, pembimbingan, hingga evaluasinya.

Peserta KKN-Tematik ini berjumlah 22 orang mahasiswa dari berbagai program studi dan fakultas yang memenuhi syarat dan kriteria tertentu. Mahasiswa tersebut dibimbing oleh tiga orang dosen pendamping lapangan dan berlangsung selama 30 hari secara daring (online). Syarat umum mahasiswa yang mengikuti KKN tematik adalah telah menyelesaikan sejumlah SKS tertentu yang ditetapkan oleh fakultas masing-masing. Para peserta yang berada di era usia generasi milenial dan aktif pada jaringan media sosial ini diharapkan mampu memberikan pengaruh bagi masyarakat lewat konten-konten kreatif yang bersifat edukatif sekaligus mengandung unsur hiburan, sehingga pemahaman masyarakat tentang COVID19 bisa lebih komprehensif. Kompetensi dasar yang dibutuhkan agar konsep dasar pembelajaran pada program KKN di masa pandemic ini dapat tercapai, diantaranya adalah (1) menganalis permasalahan yang dihadapi selama masa pandemic COVID-19; (2) menemukan ide/gagasan untuk memecahkan masalah tersebut; serta (3) merencanakan dan mewujudkan produk untuk memberi solusi yang dapat langsung diimplementasikan dalam situasi saat ini.

Mengingat kondisi pandemic yang menyebabkan keterbatasa aktivitas fisik di luar rumah, maka hotspot penyebaran informasi via social media ditentukan berdasarkan domisili peserta KKN sebagaimana yang ditunjukkan pada Gambar 1. Meskipun demikian, karena konten kreatif ini disebarkan via social media, maka jarak jangkaunnya diharapkan bisa lebih luas hingga ke seluruh Sulawesi Tenggara. 


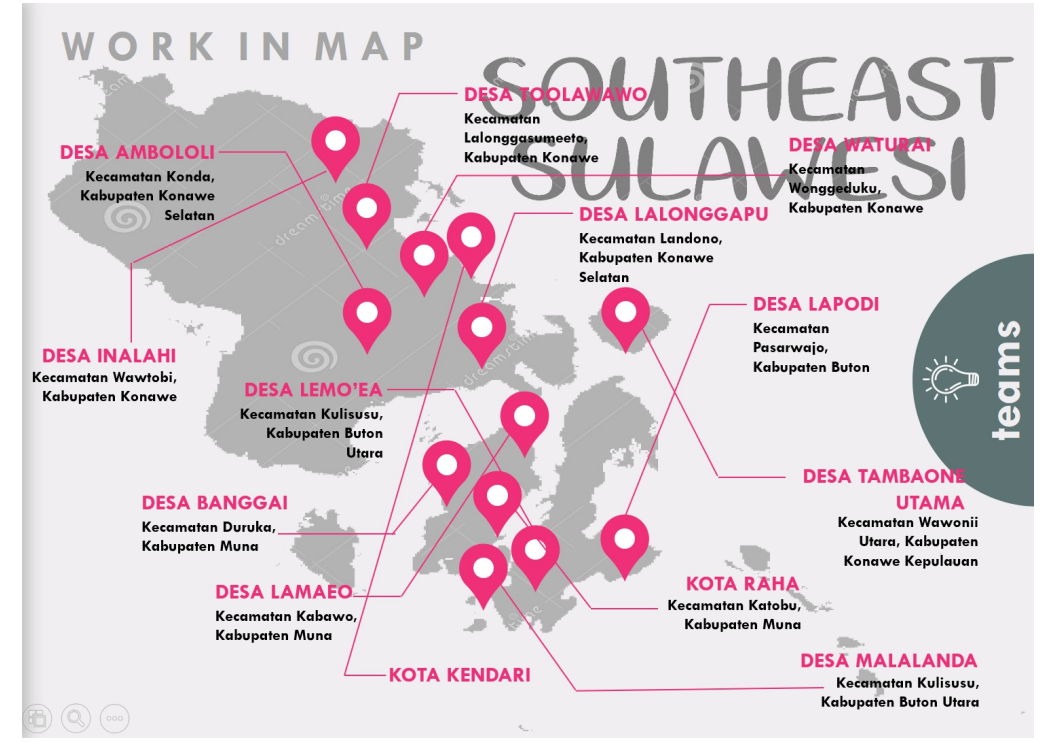

Gambar 1. Sebaran Lokasi Domisili Mahasiswa Peserta KKN-Tematik

\section{HASIL DAN PEMBAHASAN}

\section{Diagnosis}

Pada tahapan ini, Tim KKN Tematik melakukan proses identifikasi permasalahan melalui pengamatan fenomena yang diperolah pada interaksi langsung di masyarakat serta melalui kajian pustaka dan media informasi lainnya. Berdasarkan hasil diagnosis tersebut, ditemukan bahwa tingkat literasi masyarakat mengenai COVID-19 serta cara pencegahannya masih terbilang rendah. Oleh karena itu, sangatlah penting membuat perencanaan yang strategis mengenai peningkatan literasi masyarakat tersebut.

\section{Perencanaan}

Gambar 2 menunjukkan bagan perencaanaan program KKN tematik ini yang dipetakan berdasarkan permasalahan dan solusi yang ingin dicapai. Adapun Solusi yang diusulkan untuk menyelesaikan permasalah kurangnya literasi masyarakat adalah: (1) meningkatkan literasi masyarakat mengenai virus Corona dan penyakit yang ditimbulkannya (COVID19); (2) Meningkatkan literasi masyarakat mengenai social dan physical distancing sebagai upaya percepatan mitigasi COVID-19; (3) Melatih masyarakat mengenai cara penggunaan dan penyiapan cairan pencuci tangan (hand sanitizer) sendiri, masker dan APD dengan memanfaatkan bahan- bahan yang terdapat di sekitar. Keseluruhan bahan literasi dan pelatihan tersebut akan disajikan dalam format digital (video, poster, infografis) dan disampaikan kepada sasaran melalvi media internet. 


\section{Journal Publicuho}

ISSN2621-1351 (online), ISSN 2685-0729 (print)

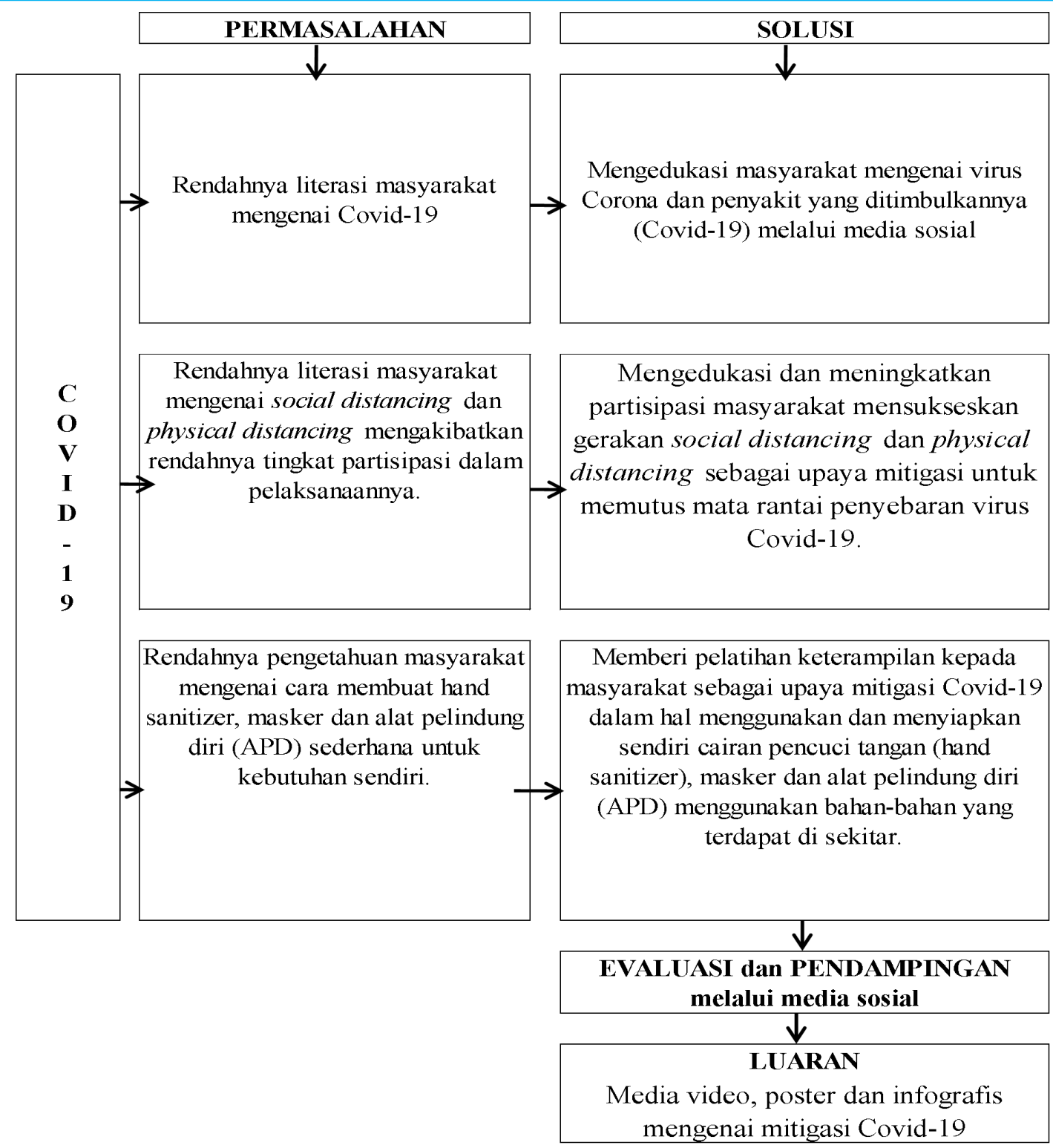

Gambar 2. Rencana Langkah-langkah Program KKN Tematik yang diusulkan

Pada tahapan ini, Tim KKN Tematik juga melakukan analisis mengenai bentuk konten kreatif serta target masyarakat sasaran yang dituju. Hal ini agar konten kreatif tersebut menarik minat masyarakat sasaran sehingga tujuan mitigasi COVID-19 dapat tercapai dan dilaksanakan dengan kesadaran penuh. Untuk mencapai target ini, mahasiswa peserta KKNTematik ini akan dibekali dengan ilmu pengetahuan dan keterampilan umum mengenai kehidupan sosial kemasyarakatan, teknik pemberdayaan dan menggali partisipasi masyarakat, dan ilmu teknologi informasi. Selain itu mereka juga akan diperkaya dengan literasi mengenai COVID-19 dan mitigasi yang dapat dilakukan untuk meminimalisir penyebarannya. 
ISSN2621-1351 (online), ISSN 2685-0729 (print

Volume 4 Number 2 (August - October), 2021 pp.834-845 Saefuddin, La Ode Santiaji B., Hasmina Tari M. DOI: $10.35817 / j p u . v 4 i 3.19663$

\section{Pelaksanaan}

Tahapan pelaksanaan KKN Tematik dilakukan dengan mendisain konten kreatif hingga mendistribusikannya ke masyarakat melalui media internet. Konten kreatif ini berupa mediamedia digital dalam bentuk poster dan video. Setiap mahasiswa peserta KKN Tematik diwajibkan membuat minimal 2 buah poster dan berkolaborasi untuk membuat video. Hingga akhir pelaksaan kegiatan KKN-Tematik ini telah dihasilkan lebih dari 20 poster/e-card dan 30 buah video. Beberapa daftar judul poster dan video yang telah dihasilkan oleh mahasiswa Tim KKN Tematik ditunjukkan pada Tabel 1 dan Tabel 2.

Tabel 1. Contoh Judul Poster/e-card yang Dihasilkan oleh Tim KKN Tematik Konten Kreatif

\begin{tabular}{llll}
\hline No & \multicolumn{1}{c}{ Judul Poster/e-card } & No & \multicolumn{1}{c}{ Judul Poster/e-card } \\
\hline 1. & Get to Know: COVID-19 & 14. & Jaga Kebersihan Masjid dan Mushola dari \\
\hline 2. & New Normat at Campus (1) & 15. & New Normal Di Lingkungan Tempat Kerja \\
\hline 3. & New Normat at Campus (2) & 16. & New Normal Starter Kit Pekerja Kantoran \\
\hline 4. & Starter Pack New Normal Saat ke & 17. & New Normal Saat Keluar Rumah \\
\hline 5. & New Normal Starter Kit & 18. & Beradaptasi Dalam New Normal \\
\hline 6. & New Normal Di Lingkungan Kerja & 19. & Starter Pack: New Normal at Campus \\
\hline 7. & Tips Penerapan New Normal Di & 20. & New Normal di Lingkungan Tempat lbadah \\
\hline 8. & Era New Normal Saat Beraktivitas & 21. & New Normal di Bandara \\
\hline 9i Kantor dan Kampus & New Normal Tempat Ibadah & 22. New Normal di Lingkungan Kampus \\
\hline 10. Tips Aman Berolahraga Di Luar Rumah & 23. New Normal di Tempat Kerja \\
\hline 11. New Normal Di Lingkungan Pasar & 24. New Normal di Pasar \\
\hline 12. New Normal & 25. 8 Benda yang Perlu Disiapkan dalam \\
\hline 13. New Normal Saat Di Kampus & \multicolumn{2}{l}{ Menjalani Kehidupan New Normal } \\
\hline
\end{tabular}

Tabel 2. Contoh Judul Video yang Dihasilkan oleh Tim KKN Tematik Konten Kreatif

\begin{tabular}{|c|c|c|}
\hline No & Judul Video & Alamat URL \\
\hline 1. & $\begin{array}{l}8 \text { Benda yang Perlu Disiapkan } \\
\text { dalam Menjalani Kehidupan } \\
\text { New Normal }\end{array}$ & $\begin{array}{l}\text { https://www.youtube.com/watch?v=0fsk9J85eAE\&list= } \\
\text { PLctTUKA5No61 ALGt4IIZSA3mo2GNHvkjy }\end{array}$ \\
\hline 2. & $\begin{array}{l}3 \text { Tentang COVID-19 yang } \\
\text { Harus Dikenali }\end{array}$ & $\begin{array}{l}\text { https://www.youtube.com/watch?v=cxpajzAgROs\&list= } \\
\text { PLctTUKA5No61 ALGt4IIZSA3mo2GNHvkjy\&index=2 }\end{array}$ \\
\hline 3. & 3 Jenis Masker Anti-Corona & $\begin{array}{l}\text { https://www.youtube.com/watch?v=ke9zcRnl17Q\&list } \\
=\text { PLctTUKA5No61 ALGt4l1ZSA3mo2GNHvkjy\&index=3 }\end{array}$ \\
\hline 4. & $\begin{array}{l}9 \text { Level Tempat dan Aktivitas } \\
\text { Beresiko COVID-19 di Era New } \\
\text { Normal }\end{array}$ & $\begin{array}{l}\text { https://www.youtube.com/watch?v=b1B6gT3NI- } \\
\text { c\&list=PLctTUKA5No61 ALGt4l1ZSA3mo2GNHvkjy\&index } \\
=4\end{array}$ \\
\hline 5. & 18 Aturan Protokol di Mall & $\begin{array}{l}\text { https://www.youtube.com/watch? } v=\mathrm{c}- \\
\text { rGuovsDkY\&list=PLctTUKA5No61 ALG+4l1ZSA3mo2GNHvk } \\
\text { jy\&index=5 }\end{array}$ \\
\hline
\end{tabular}




\section{Journal Publicuho}

ISSN2621-1351 (online), ISSN 2685-0729 (print)

Volume 4 Number 3 (August - October), 2021 pp. 834-845

Accredited SINTA SK.NOMOR 28/E/KPT/2019 Open Access at:http://ojs.uho.ac.id/index.php/PUBLICUHO/index DOI: 10.35817/jpu.v4i3.19663

6. 12 Protokol Kesehatan Tempat https://www.youtube.com/watch? $v=5 \mathrm{VzQRWOST9s \& lis}$ Ibadah di Era New Normal t=PLctTUKA5No61 ALGt4l1ZSA3mo2GNHvkjy\&index=6

7. 3 Persamaan Sekaligus https://www.youtube.com/watch? $v=u 50 g 312$ RyU8\&list Perbedaan Antara Physical =PLctTUKA5No61ALGt4I1ZSA3mo2GNHvkjy\&index=9 dengan Social Distancing

8. 6 Tanda Seorang Covidiot https://www.youtube.com/watch?v=MaaKcE9npew\&li $\mathrm{st}=$ PLC†TUKA5No61ALG†4I1ZSA3mo2GNHvkjy\&index $=12$

9. Covidiot Starter Pack (dalam Bahasa Inggris)

https://www.youtube.com/watch? $v=$ =IIEUV3TEsrE\&list=P LC†TUKA5No61ALG+4l1ZSA3mo2GNHvkjy\&index=13

10. Mahasiswa Sehat, Kuat dan Kreatif untuk Indonesia

https://www.youtube.com/watch? $v=h j-$ mIZMgZrs\&list=PLc†TUKA5No61ALG†4IIZSA3mo2GNHvkjy \&index $=11$

11. Profil Tim KKN Tematik 2020

https://www.youtube.com/watch? $v=X$ SWIGQhE6vA\&lis $\dagger=P L C \dagger T U K A 5 N o 61$ ALG†4I1ZSA3mo2GNHvkjy\&index=8

Konten poster dan video yang dibuat diarahkan agar mengusung berbagai topik mengenai COVID-19, mulai dari literasi tentang virusnya, cara penyebaran, upaya pencegahan hingga perilaku yang dapat dilakukan oleh masyarakat untuk meminimalisir penyebaran virus tersebut. Sementara mengenai disain dan presentasi media tersebut sepenuhnya diserahkan pada kreativitas mahasiswa masing-masing.

Keseluruhan poster dan video yang dibuat kemudian disebarkan di berbagai media sosial melalui akun-akun mahasiswa dan dosen pembimbing serta media internet lainnya. Media sosial tersebut adalah facebook, twitter, instagram dan youtube. Contoh tampilan poster dan video diperlihatkan pada Gambar 3-4.

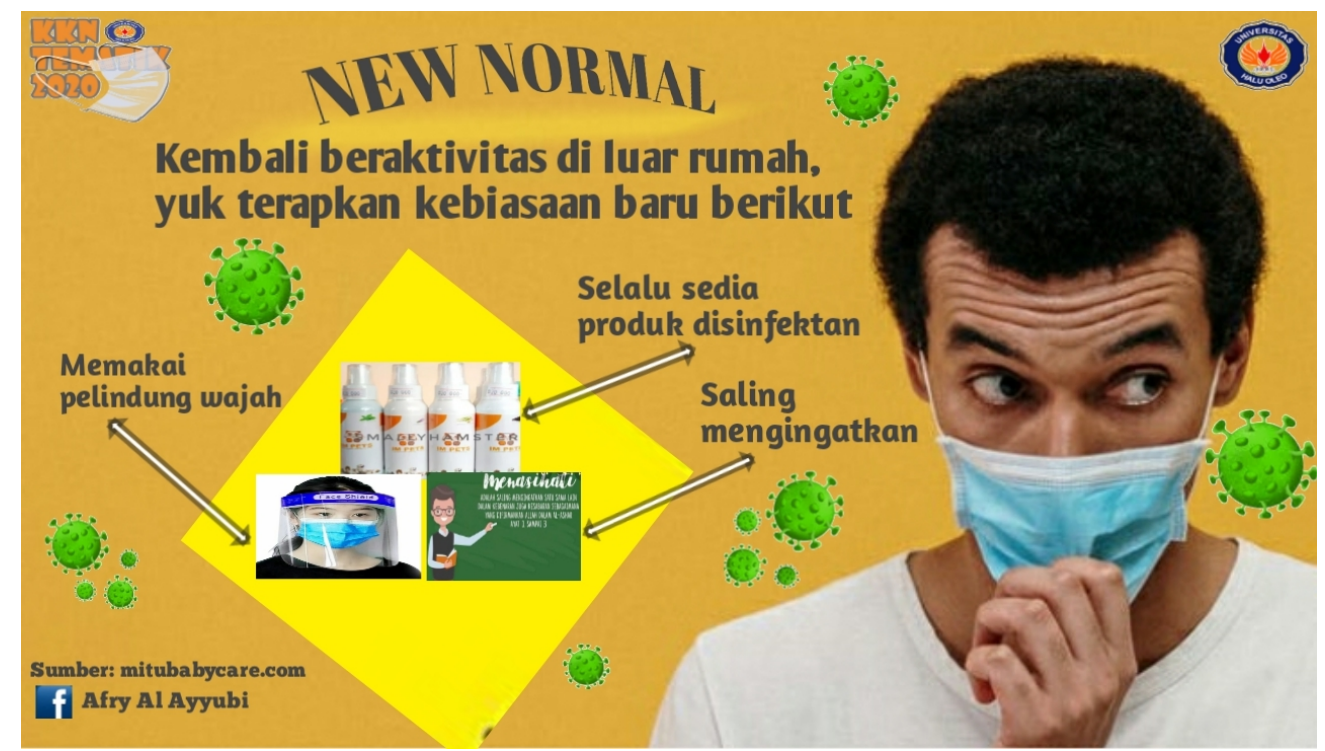



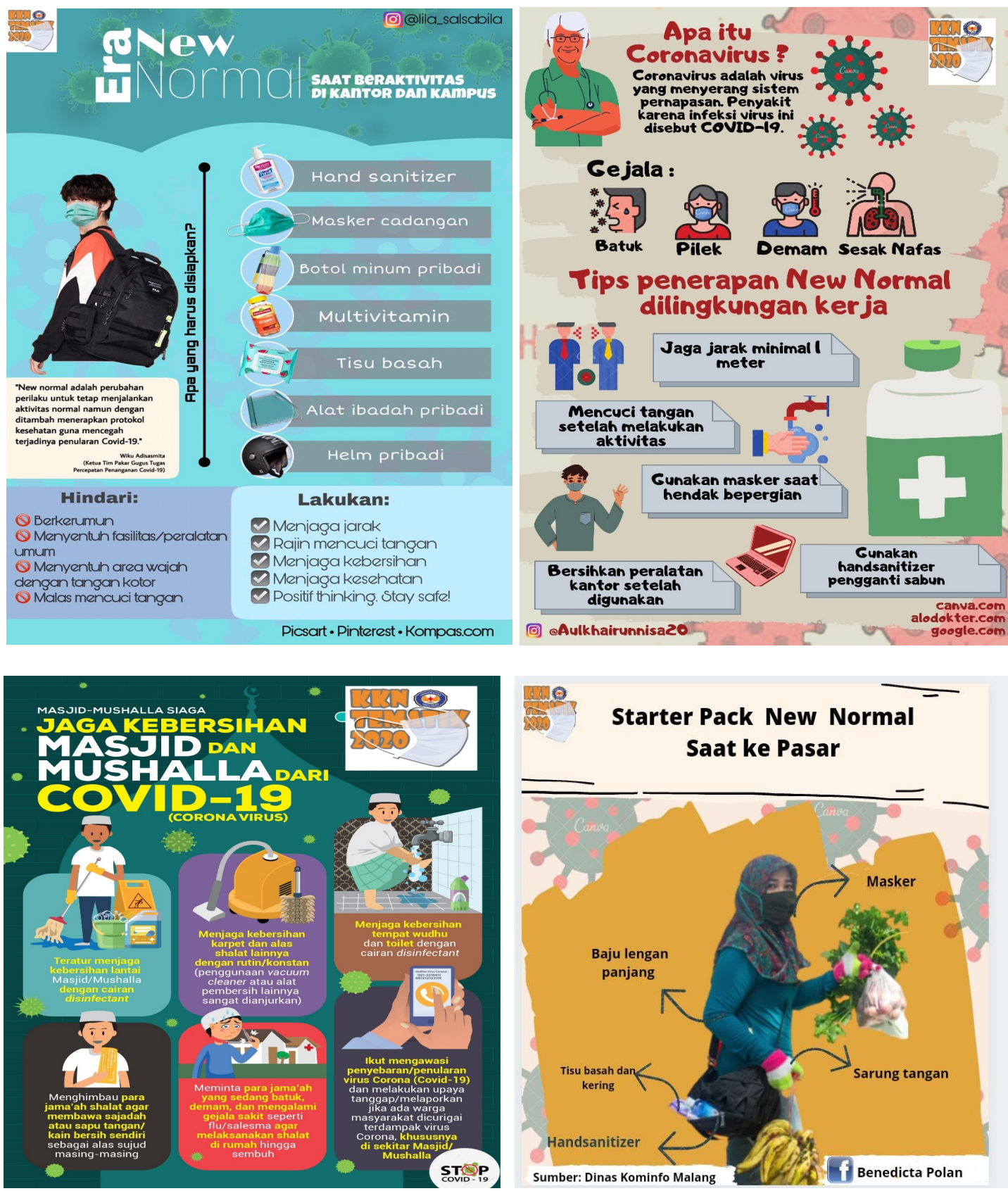

Gambar 3. Contoh e-poster yang Dihasilkan oleh Tim KKN Tematik Konten Kreatif 


\section{Journal Publicuho}

ISSN2621-1351 (online), ISSN 2685-0729 (print)

Volume 4 Number 3 (August - October), 2021 pp. 834-845

Accredited SINTA SK.NOMOR 28/E/KPT/2019

Open Access at:http://ojs.uho.ac.id/index.php/PUBLICUHO/index DOI: 10.35817/jpu.v4i3.19663
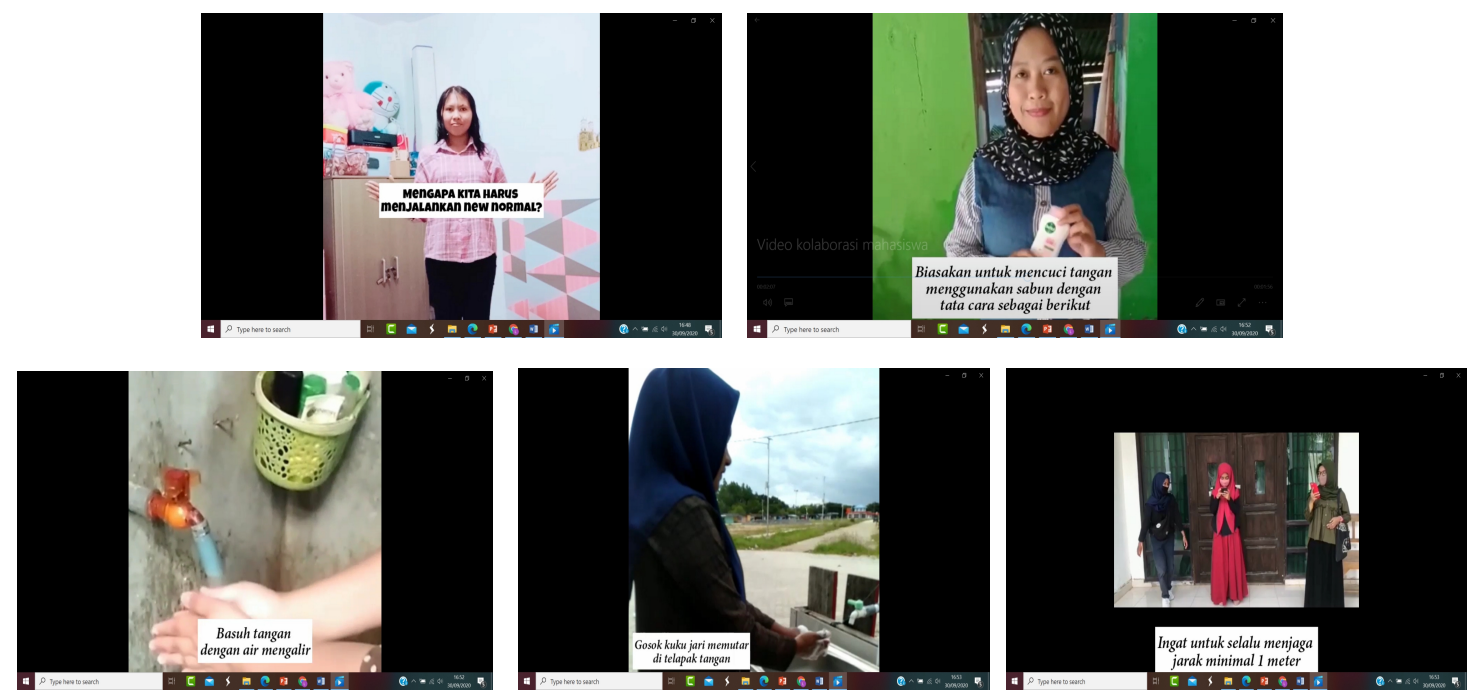

Gambar 4. Screenshoot Contoh Video yang Dihasilkan oleh Tim KKN Tematik Konten Kreatif

\section{Evaluasi}

Tahapan evaluasi dilakukan secara umum dengan melihat animo masyarakat yang dapat mengakses e-poster serta video tersebut. Berdasarkan hasil diskusi seluruh Tim KKN tematik, dapat disimpulkan bahwa konten kreatif berupa video dan e-poster tersebut mendapatkan respon dan komentar yang positif dari netizen yang melihatnya.

\section{Pembelajaran Khusus}

KKN Tematik yang bertujuan untuk meningkatkan literasi masyarakat mengenai COVID-19 serta cara mitigasinya telah terlaksana dengan baik. Mengingat masa pandemik COVID-19 yang masih berlangsung, dosen pengampu mata kuliah di perguruan tinggi dapat mengimplementasikan metode ini dengan cara memberi tugas tambahan kepada mahasiswa peserta kuliahnya untuk membuat konten kreatif baik berupa poster/e-card dan/atau video yang harus disebarkan melalui akun media sosial masing-masing. Poster tersebut dapat memiliki tema yang berbeda sesuai dengan mata kuliahnya ataupun topik mengenai COVID-19, utamanya upaya-upaya yang dapat dilakukan oleh masyarakat untuk percepatan mitigasi wabah ini. Selain itu, e-poster yang telah dibuat dapat direplikasi oleh lembaga/institusi untuk dicetak dan dipasang pada lokasi-lokasi yang ramai dan strategist agar masyarakat selalu teringat pada pelaksanaan protocol Kesehatan terkait COVID-19 agar masa pandamik ini bisa segera berlalu. 


\section{KESIMPULAN}

Program KKN Tematik mengenai pemanfaatan internet untuk mitigasi COVID-19 telah terlaksana dengan baik sesuai tujuan yang diharapkan. Penyebaran konten kreatif melalui social media terbukti telah dapat mengedukasi dan meningkatkan literasi masyarakat mengenai virus Corona dan penyakit yang ditimbulkannya (Covid-19) serta upaya yang bisa dilakukan oleh masyarakat untuk meminimalisir dampaknya. Jangkauan media sosial yang luas dan tayang selama 24 jam menjadi nilai positif yang dapat dimaksimalkan pemanfaatannya.

\section{UCAPAN TERIMA KASIH}

Terima kasih kepada Universitas Halu Oleo yang mendanai kegiatan Pengabdian Masyarakat terintegrasi KKN Tematik ini melalui Dana DIPA Universitas Halu Oleo Tahun Anggaran 2020 dengan Surat Perjanjian Pelaksanaan Pekerjaan Nomor. 768n/UN29.20/PPM /2020. Terima kasih kepada seluruh pihak yang telah membantu dalam proses diseminasi kegiatan ini baik melalui media sosial, media online maupun media lainnya. Terima kasih dan apresiasi sebesar-besarnya kepada mahasiswa peserta KKN Tematik ini yaitu: Listianingsi, Sumiarni, Misnayanti, Diky, Yusman, Andi Rasmiyana, Fitrianti Wulandari, Afriyanto, Benedicta Polan, Irwan, Alimansyah M, Almeira Salsabila, Anna Fauziah Ramli, Aulia Khairunnisa, Wan Azizah, Waode Rosmilawati, Windi Nur Aulia, Yusril Andriananto, Zhafira Miranda, Ni Luh Nadya Laksmi U., Nirma Selastiana R., dan Nur Zainab.

\section{REFERENSI}

Agwu, P., Ugwu, C.M. and Eke, C.F., 2020. Community engagement in COVID-19 responses: Evidence from qualitative interface with community opinion leaders in Enugu, Nigeria. ASEAN Journal of Community Engagement, 4(2), pp.416-434.

Amadasun, S., 2020. Social work and COVID-19 pandemic: An action call. International Social Work, 63(6), pp.753-756.

Bdair, I.A., 2021. Nursing students' and faculty members' perspectives about online learning during COVID-19 pandemic: A qualitative study. Teaching and Learning in Nursing, [online] 000, pp.1-7. Available at: <https://doi.org/10.1016/j.teln.2021.02.008>.

Feldman, A., 2020. Science Teacher Action Research in the Time of the COVID-19 Pandemic. Action Research and Innovation in Science Education, [online] 3(2), pp.25-26. Available at: <https://doi.org/10.12973/arise/512463>.

Harring, N., Jagers, S.C. and Löfgren, A., 2021. COVID-19: Large-scale collective action, government intervention, and the importance of trust. World Development, .

Jogezai, N.A., Baloch, F.A., Jaffar, M., Shah, T., Khilji, G.K. and Bashir, S., 2021. Teachers' attitudes towards social media (SM) use in online learning amid the COVID-19 pandemic: the effects of SM use by teachers and religious scholars during physical distancing. Heliyon, [online] 7(4), p.e06781. Available at: <https://doi.org/10.1016/j.heliyon.2021.e06781>. 


\section{Journal Publicuho}

ISSN2621-1351 (online), ISSN 2685-0729 (print)

Volume 4 Number 3 (August - October), 2021 pp. 834-845

Accredited SINTA SK.NOMOR 28/E/KPT/2019

Open Access at:http://ojs.uho.ac.id/index.php/PUBLICUHO/index DOI: 10.35817/jpu.v4i3.19663

Kesehatan, K., 2020. Pedoman Pencegahan dan Pengendalian Corona Virus deases (Covid19). Kementrian Kesehatan, [online] 5, p.178. Available at: <https://covid19.go.id/storage/app/media/Protokol/REV-05_Pedoman_P2_COVID19_13_Juli_2020.pdf>.

Lapitan, L.D., Tiangco, C.E., Sumalinog, D.A.G., Sabarillo, N.S. and Diaz, J.M., 2021. An effective blended online teaching and learning strategy during the COVID-19 pandemic. Education for Chemical Engineers, [online] 35(May 2020), pp.116-131. Available at: <https://doi.org/10.1016/j.ece.2021.01.012>.

Madden, D., Cadet-James, Y., Atkinson, I. and Watkin Lui, F., 2014. Probes and prototypes: A participatory action research approach to codesign. CoDesign, 10(1), pp.31-45.

Mohd Syafiq Aiman Mat Noor, Satirah Ahmad and Zailah Zainudin, 2020. Initiating a professional development on action research during the COVID-19 pandemic I. Nali Symposium, (December), pp.394-407.

Mokui, H.T., Pagiling, L., Tachrir, T. and Rachman, R.M., 2021. Evaluasi Program Pendampingan Pembuatan Perangkat Cuci Tangan Otomatis Dalam Upaya Mitigasi COVID-19 di Sulawesi Tenggara. Journal Publicuho, [online] 4(2), pp.729-737. Available at: <http://ojs.uho.ac.id/index.php/PUBLICUHO/article/view/18894>.

Park, A., Chang, H. and Jun Lee, K., 2017. Action research on development and application of internet of things services in hospital. Healthcare Informatics Research, 23(1), pp.2534.

Wirani, N., 2020. Pentingnya Penggunaan Model Pembelajaran Berbasis Web Untuk Mencegah Penyebaran Covid-19. AlÁdzkiya International of Education and Sosial, p.23.

Zhao, Y., Cheng, S., Yu, X. and XU, H., 2020. Chinese public's attention to the COVID-19 epidemic on social media: Observational descriptive study. Journal of Medical Internet Research, 22(5), pp.1-13. 